\title{
MAGNETIC FABRICS OF THE TERTIARY VRONDOU PLUTONIC COMPLEX, NORTHERN GREECE.
}

\author{
Zananiri I. ${ }^{1}$, Dimitriadis S. ${ }^{2}$, Kondopoulou D. ${ }^{1}$, and Kilias A. ${ }^{3}$ \\ ${ }^{1}$ Department of Geophysics, School of Geology, Aristotle University of Thessaloniki, 54621 , \\ Thessaloniki,izanan@lemnos.geo.auth.gr,despi@geo.auth.gr
}

2 Department of Mineralogy-Petrology-Economic Geology, School of Geology, Aristotle University of Thessaloniki, 546 21, Thessaloniki, sarantis@geo.auth.gr

${ }^{3}$ Department of Geology, School of Geology, Aristotle University of Thessaloniki, 54621 , Thessaloniki,kilias@geo.auth.gr

\begin{abstract}
The emplacement and tectonic evolution of the Tertiary Vrondou granitoid in the Greek Rhodope has been studied by a combination of field tectonic, microtextural and anisotropy of magnetic susceptibility (AMS) methods. The Vrondou pluton is composed of at least two intrusions: a Mid-Oligocene one at its eastern and an Early Miocene at its western parts. Room for the emplacement in both cases was provided by the opening of an extensional ramp space within a several $\mathrm{km}$ thick, mid-crustal subhorizontal shear zone, with a top to the SW sense, active during the Mid-Oligocene to Early Miocene period. The older eastern part of the pluton is much less deformed than the younger western part. Magmatic textures are well preserved in the older intrusion whereas they are scarcely present in the younger one. They indicate a NW-SE direction of magmatic flow in both cases. Sub-solidus plastic deformation affected mostly the younger western part of the pluton and only locally the older eastern one. In both cases mineral lineations trending NE-SW were developed. An increase in the shear rate by the Early Miocene or a localization of shear mainly in the west, in combination with the more silica saturated rock types present there, are probably the reasons for the different deformational behaviour of the two parts of the pluton.
\end{abstract}

\section{INTRODUCTION}

The anisotropy of magnetic susceptibility (AMS) has become a powerful tool for unravelling the emplacement, cooling and deformational history of granitic plutons (e.g. Bouchez et al. 1990, Trindade et al. 1999). AMS can detect feeble anisotropies imperceptible in the field, imprinted in the rock either at super-solidus temperatures during the emplacement of partly crystallized magmatic bodies, or shortly after their complete crystallization at sub-solidus yet relatively high temperatures, or even long after their emplacement, crystallization and cooling. Once such magnetic anisotropies and their principal orientations are identified by AMS, re-examination of field exposures and careful study of oriented thin sections or polished slabs may reveal mineral and fabric anisotropies which otherwise could have passed unnoticed. In certain cases AMS can also provide clues as to the mechanism and kinematics responsible for the observed anisotropy.

In this paper we present the results of a combined AMS and microtextural study of the approx. $300 \mathrm{~km}^{2}$ Vrondou granitic pluton, northern Greece. Vrondou is one of the several Tertiary plutonic bodies that intruded in the metamorphic formations of the Rhodope massif (Fig. 1).

Petrological aspects of the Tertiary granitic rocks emplaced in the Rhodope can be found in several unpublished Theses (Papadakis 1965, Christofides 1977, Sklavounos 1981, Theodorikas 1982, Soldatos 1985, Kyriakopoulos 1987, Kolokotroni 1992). General reviews of the Tertiary magmatism in the Rhodope were presented by Jones et al. (1992) and Christofides et al. (2001).

A lot of work has been done concerning the Tertiary tectonic evolution of the Rhodope (Kronberg 1969, Kronberg et al. 1970, Burg et al. 1990, Koukouvelas \& Doutsos 1990, Dinter \& Royden 
1993, Dinter 1991, 1994, Dimitriadis 1995, Burg et al. 1995, Dimitriadis et al. 1998, Kilias \& Mountrakis 1998, Mposkos 1998, Soldatos et al. 1998, Kilias et al. 2002). This is characterized by the presence of a several $\mathrm{km}$ thick mid crustal subhorizontal shear zone with a top to the SW sense of shear, which affected successively the Rhodopian units from top to bottom during Eocene to Oligocene - Miocene times. Southwest sense of movement was associated with greenschist to amphibolite facies metamorphism and syn-extensional granite intrusions during the Oligocene and the Early Miocene. The whole complex was elevated and finally exhumed its core via an extensional unroofing that started by the Middle Miocene and resulted in the opening of the Strymon Valley (Dinter 1991, 1994, Dinter \& Royden 1993). The Strymon Valley detachment fault actually bounds the Vrondou pluton from the west (Fig. 1).

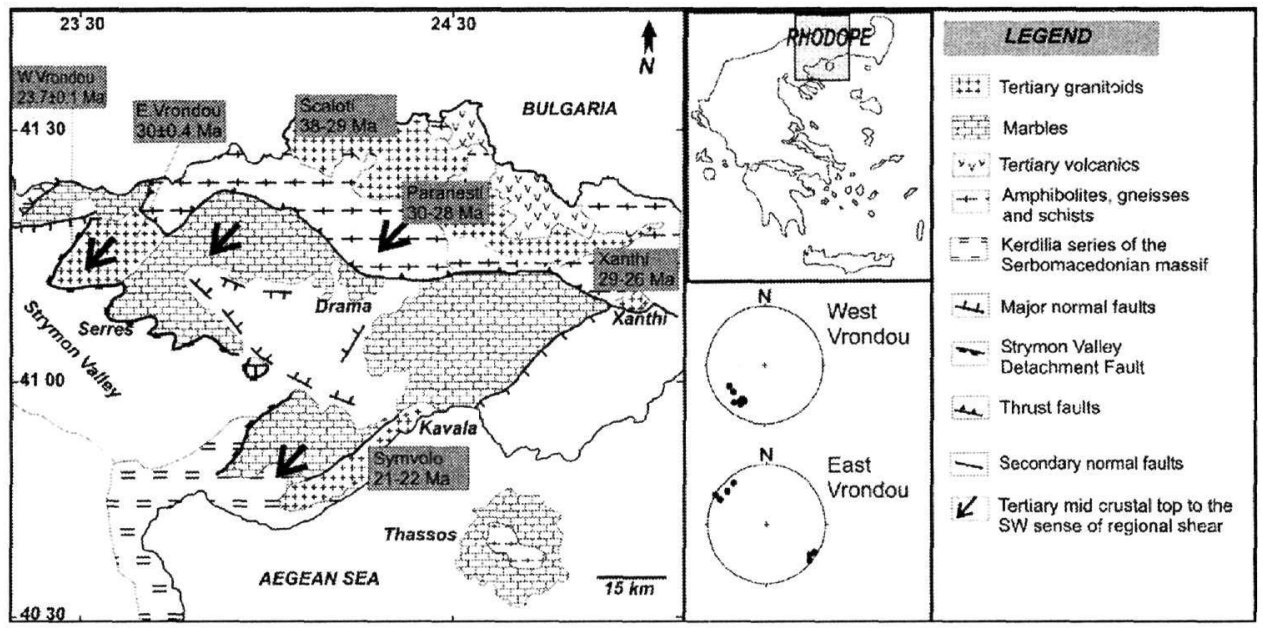

Figure 1. Tertiary granitoid intrusions (with their isotopic ages) and the main lithological and tectonic features of the Greek Rhodope. (After Kilias \& Mountrakis 1998). The two stereoplots represent stretching lineations measured in the present study in western and eastern Vrondou.

Vrondou is a petrologically composite pluton, with granitic, syenitic, granodioritic, monzonitic and quartz monzonitic parts (Fig. 2a). According to the most recent and reliable radiometric age determinations (Ar-Ar in hornblende and U-Pb in titanite, Kauffman 1995, Dinter et al. 1995) the pluton was formed by at least two distinctive intrusive events separated by several million years. During the earlier one, of Mid-Oligocene age ( $30 \pm 0.4 \mathrm{Ma}, \mathrm{Ar}-\mathrm{Ar}$ in hornblende) the monzonitic and granodioritic types were emplaced in the eastern part of the composite pluton, whereas during the later, of latest Oligocene to Early Miocene age $(23.7 \pm 0.1 \mathrm{Ma}, \mathrm{U}-\mathrm{Pb}$ in titanite) the more silica saturated granitic and quartz monzonitic types were emplaced in its western part. No clear-cut contacts between the crystallized products of these two emplacement events have however been identified in the field.

A subhorizontal planar fabric with top to the SW sense of shear is strongly imprinted in the south-western, younger part of the pluton and has been generally interpreted as due to a "synemplacement" Early Miocene deformation event. This same fabric, less well developed, is however also present, though only locally, at the eastern, older part of the pluton.

It has been proposed (Kolokotroni \& Dixon 1991, Kolokotroni 1992) that the Vrondou pluton was emplaced by influx of magma into a flat extensional ramp space, laterally bounded at the last stages of intrusion by a steep dextral wrench shear pair. This model is consistent with the shallow stretching and mineral lineations trending NE-SW, mainly seen in the central and southwestern parts of the pluton. The same authors have also suggested on geochemical evidence that the sequence of intrusions and the movement of a "crystallization front" in Vrondou was from SW to NE. This latter is at variance to the results of the age determinations referred above. 


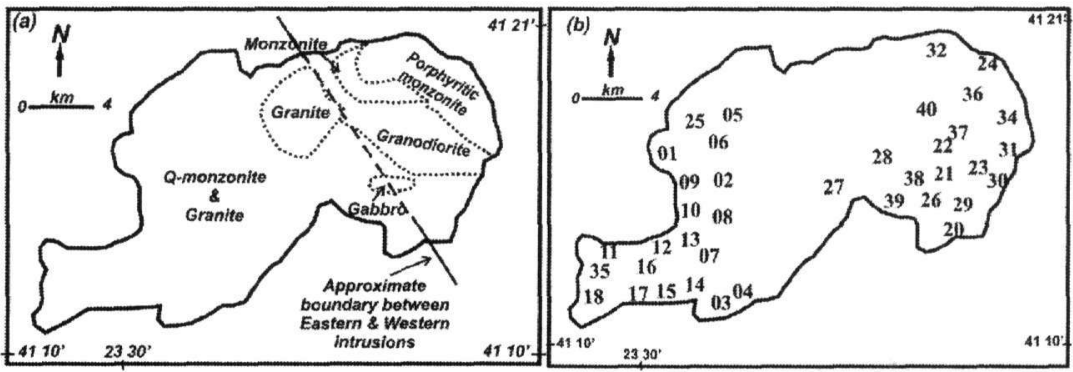

Figure 2. (a) Petrographic types of the Vrondou pluton. (After Kolokotroni 1992), (b) Sampling sites in the Vrondou pluton.

A combined AMS and microtextural analysis of the state and spatial distribution of deformation covering both parts of the pluton could help understand the emplacement sequence and the reasons for the observed differences in the deformational behaviour between these two parts. This is the aim of the present study, preliminary results of which have, already been presented in Zananiri et al. 2002).

\section{SAMPLING AND MEASUREMENTS}

Drilled cores and oriented hand samples were collected at 40 sites (Fig. 2b). Sampling was restricted only in areas exposing fresh rock; due to its deep weathering most of the central part of the pluton was for this reason left out.

Both AMS and palaeomagnetic measurements were performed on the collected samples. Thermomagnetic analyses and isothermal remanent magnetization (IRM) measurements were carried out to investigate the magnetic mineralogy. Microscopic examination of oriented thin sections helped characterizing the microstructures. All these data were combined with field structural data.

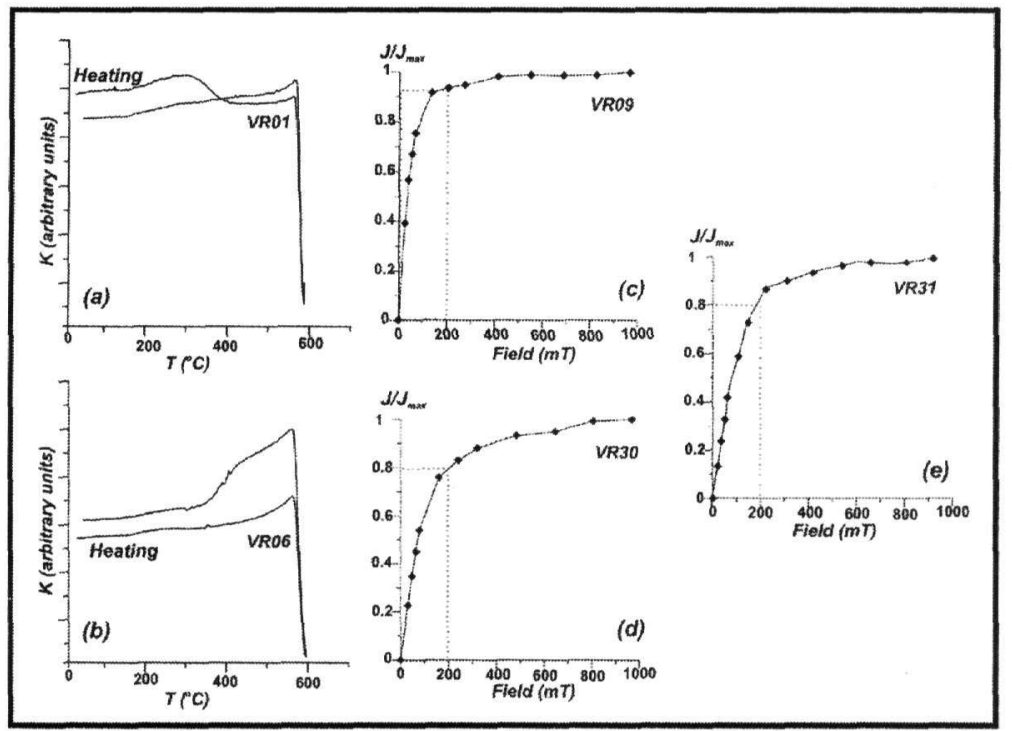

Figure 3. Representative thermomagnetic (a)-(b) and IRM acquisition (c)-(d)-(e) curves.

\section{MAGNETIC MINERALOGY}

Palaeomagnetic and rock magnetic experiments were performed at the Palaeomagnetic Laboratory of the Aristotle University of Thessaloniki. Representative thermomagnetic curves (Fig. 3a,b) show that the magnetic susceptibility $K$ decreases to zero at $580^{\circ} \mathrm{C}$, the Curie temperature typical of 
magnetite. Stepwise acquisition of the IRM indicates that more than $80 \%$ of saturation is reached at fields lower than $200 \mathrm{mT}$ (Fig. 3c,d,e). Thus, magnetite as the main magnetic carrier can be assumed, along with the presence of small amounts of hematite. The Lowrie-Fuller (1971) and Cisowski (1981) tests suggest that the remanence carrier is mostly multi-domain magnetite. Magnetite as the prevailing magnetic phase is also verified by thermal and AF-demagnetization experiments. Combining the results of the thermomagnetic curves and the Lowrie-Fuller tests we can assume that we have a mixture of coarse- and fine-grained magnetites.

\section{ANISOTROPY OF MAGNETIC SUSCEPTIBILITY}

The anisotropy of the magnetic susceptibility was measured with the Kappabridge KLY-2 and KLY-3 apparatuses at the Palaeomagnetic Laboratories of the Universities of Plymouth (UK), Sofia (Bulgaria) and Turin (Italy). A few samples were measured at all three laboratories to ensure accuracy and compatibility of the data sets. Each AMS measurement yields the magnitudes of the three principal orthogonal axes of the AMS ellipsoid $\left(K_{1} \geq K_{2} \geq K_{3}\right)$, and their declinations and inclinations with respect to the geographical frame. The bulk magnetic susceptibility magnitude is given by $\mathrm{K}_{\mathrm{m}}=$ $\left(\mathrm{K}_{1}+\mathrm{K}_{2}+\mathrm{K}_{3}\right)$ /3. The anisotropy degree $\mathrm{P}^{\prime}=\exp \sqrt{2\left[\left(\ln \frac{\mathrm{K}_{1}}{\mathrm{~K}_{\mathrm{m}}}\right)^{2}+\left(\ln \frac{\mathrm{K}_{2}}{\mathrm{~K}_{\mathrm{m}}}\right)^{2}+\left(\ln \frac{\mathrm{K}_{3}}{\mathrm{~K}_{\mathrm{m}}}\right)^{2}\right]}$, and the shape parameter of Jelinek (1981) $T=(\ln F-\ln L) /(\ln F+\ln L)$, where $F=K_{2} / K_{3}$ and $L=K_{1} / K_{2}$, were also calculated. Table 1 gives averages of the AMS data at each of the 40 sites.

\subsection{Scalar AMS data}

The measured scalar AMS parameters vary significantly throughout the examined parts of the pluton, but the western and eastern Vrondou have clearly different behaviuurs. In western Vrondou susceptibility ranges from $1.120 \times 10^{-3}$ to $48 \times 10^{-3} \mathrm{SI}$, with a unimodal distribution and a frequency peak around $10 \times 10^{-3} \mathrm{SI}$ (Fig. 4a,b). Eastern Vrondou on the other hand exhibits much lower mean susceptibilities, ranging from $0.255 \times 10^{-3}$ to $36.020 \times 10^{-3} \mathrm{SI}$, with a bimodal distribution, the major peak being at very low values $\left(<10^{-3} \mathrm{SI}\right)$ and the other at intermediate values $\left(\sim 10 \times 10^{-3} \mathrm{SI}\right)$. Note that the main peaks of the two distributions differ by one order of magnitude.

Examining the magnetic susceptibility (K) versus the anisotropy degree ( $\left.P^{\prime}\right)$ (Fig. 4c,d) other differences between the two areas become evident. In western Vrondou the anisotropy degree is high, ranging from 13 to $55 \%$, with a mean value of $37 \%$. A linear correlation is observed between $K$ and $P^{\prime}$, as is usually the case for magnetite-bearing plutons (Bouchez 1997). In the eastern Vrondou the anisotropy ranges between 5 and $56 \%$, but anisotropies higher than $30 \%$ are present only in 3 sites, with a mean at $18 \%$. The $P^{\prime}$ versus $K$ plot does not show any correlation between the two parameters.

As to the shape of the AMS ellipsoid (Fig. 4e,f), in western Vrondou the $T$ values range from -0.191 to 0.881 , with a mean at 0.350 , indicating that oblate ellipsoids prevail. The $T$ versus $P^{\prime}$ plot points to the lack of prolate-shaped ellipsoids. Noteworthy is the trajectory of $T$ with increasing anisotropy degree. The dashed line in figure $5 \mathrm{e}$ first follows a curve of regression and then changes to a steep increase, approaching the shape of a parabola. Similar paths have been referred by Borradaile \& Henry (1997) for sedimentary strained rocks, where the Jelinek plot showed the general trend of the AMS ellipsoid during deformation. In eastern Vrondou the picture is totally different. The shape parameter $T$ ranges widely from -0.737 to 0.874 , and in the $T\left(P^{\prime}\right)$ plot two distinct concentrations are present; one in the positive $T$ - low $P^{\prime}$ domain with a mean value of 0.415 , and the other in the negative $T$ - high $P$ ' domain with a mean of -0.200 . Hence, with increasing anisotropy the AMS ellipsoid changes from oblate to prolate. These very different $T\left(P^{\prime}\right)$ trajectories point to different deformation paths for the western and eastern parts of the pluton. 


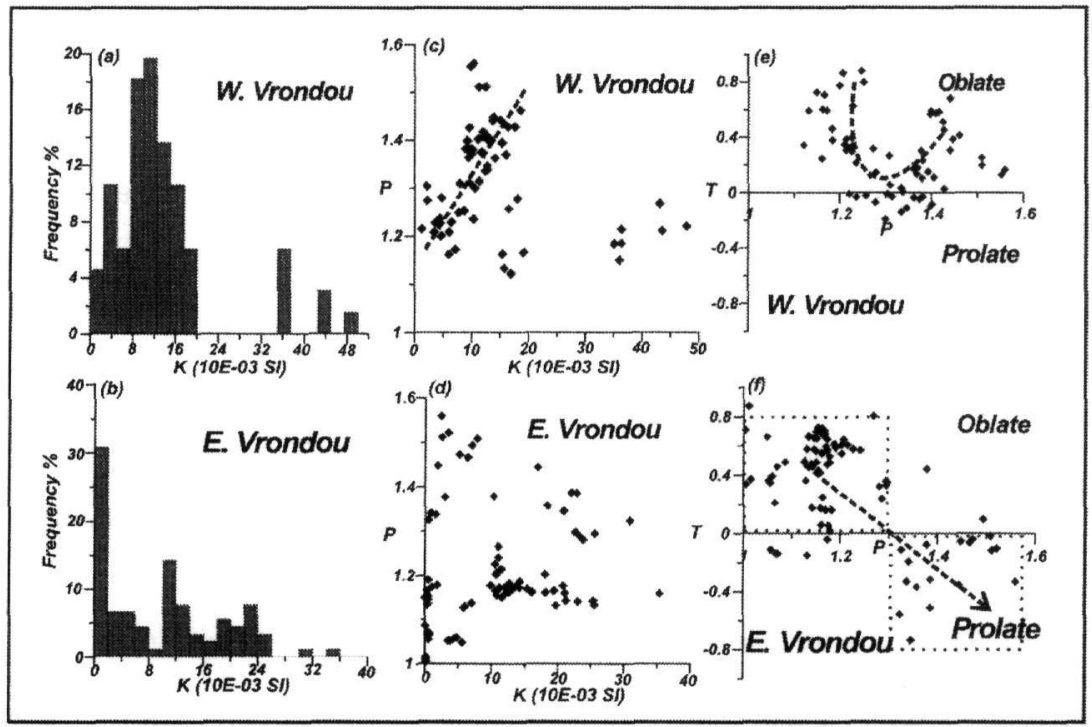

Figure 4. AMS scalar data for western and eastern Vrondou: (a)-(b) $K$ value frequency histogram; (c)-(d) $P^{\prime}$ vs. $K$ plot; (e)-(f) P'vs. T plot.

\subsection{Magnetic fabric}

The magnetic fabrics throughout the studied parts of the Vrondou pluton are well defined, allowing thus reliable interpretations. The prevailing magnetic lineation $\left(\mathrm{K}_{1}\right)$ in the strongly deformed western part of the pluton is subhorizontal and trends NE-SW (Fig. 5a) parallel to the mylonitic mineral lineation of these rocks. However, at a few sites magnetic lineations trending NW-SE were recorded. These are related with rocks preserving magmatic textures.

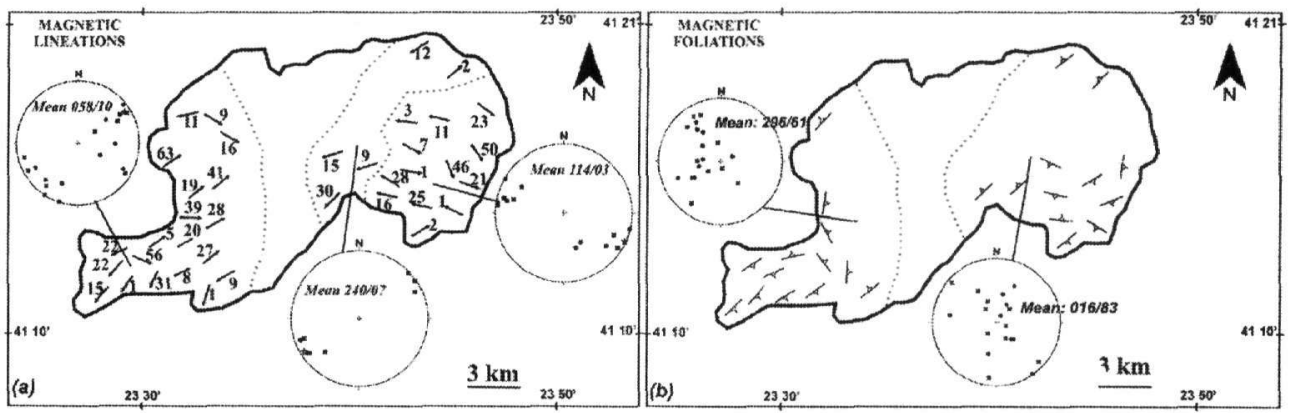

Figure 5. a) Magnetic lineations ( $K_{1}$ axe with plunges in degrees), Schmidt plots (lower hemisphere) and average orientations in the west and east of Vrondou. b) Magnetic foliations in the different sub-domains of the Vrondou pluton, Schmidt plots of $\mathrm{K}_{3}$ axes and average orientations in the west and east of Vrondou. In both figures, the dashed lines distinguish between the parts of the pluton where the stereoplots are valid.

By contrast, the prevailing magnetic lineation in the almost undeformed, eastern part of the pluton is also close to horizontal but trends NW-SE (Fig. 5a). However, a few sites yield NE-SW magnetic lineations and these are related with rocks bearing indications of post-crystallization deformation. The above differences between the eastern and the western parts of the pluton may be attributed to their different responses under the same stress field.

Both in eastern and western Vrondou $\mathrm{K}_{3}$ axes are mostly subvertical, defining subhorizontal foliation planes (Fig $5 b$ ). The few sites that exhibit steep $K_{1}-K_{2}$ planes are close to the borders of the pluton and may be related either to magmatic flow close to steep bordering "walls", or to marginal deflections of originally subhorizontal foliation planes during the exhumation stage. 
Table 1. Average AMS data for each sampling site from the Vrondou pluton

\begin{tabular}{|c|c|c|c|c|c|c|c|c|c|}
\hline Site & $\mathbf{N}$ & $\mathrm{K}_{m} \times 10^{-3}$ & $L$ & $F$ & $P^{\prime}$ & $T$ & $\begin{array}{c}\mathrm{K}_{\max } \\
\text { (Dec/lnc) }\end{array}$ & $\begin{array}{c}\mathrm{K}_{\text {int }} \\
\text { (Dec/lnc) }\end{array}$ & $\begin{array}{c}\mathrm{K}_{\min } \\
(\mathrm{Dec} / \mathrm{lnc})\end{array}$ \\
\hline 1 & 7 & 18.910 & 1.074 & 1.149 & 1.233 & 0.337 & $056 / 63$ & $155 / 03$ & $249 / 27$ \\
\hline 2 & 8 & 10.311 & 1.172 & 1.133 & 1.328 & -0.122 & $051 / 41$ & $148 / 07$ & $239 / 49$ \\
\hline 3 & 16 & 2.012 & 1.080 & 1.140 & 1.232 & 0.320 & 198/01 & $112 / 33$ & $310 / 58$ \\
\hline 4 & 8 & 14.900 & 1.126 & 1.156 & 1.303 & 0.118 & $241 / 09$ & $339 / 33$ & $141 / 54$ \\
\hline 5 & 6 & 9.866 & 1.063 & 1.059 & 1.126 & -0.074 & $122 / 09$ & $218 / 03$ & $215 / 19$ \\
\hline 6 & 7 & 16.421 & 1.055 & 1.103 & 1.164 & 0.353 & $119 / 16$ & $021 / 55$ & $352 / 65$ \\
\hline 7 & 4 & 10.946 & 1.187 & 1.289 & 1.534 & 0.184 & $062 / 27$ & $171 / 39$ & $272 / 59$ \\
\hline 8 & 4 & 19.199 & 1.116 & 1.283 & 1.445 & 0.391 & $062 / 28$ & $156 / 07$ & $258 / 61$ \\
\hline 9 & 4 & 12.903 & 1.067 & 1.303 & 1.417 & 0.608 & $056 / 19$ & $153 / 14$ & $278 / 67$ \\
\hline 10 & 5 & 16.407 & 1.150 & 1.169 & 1.345 & 0.044 & $091 / 39$ & $348 / 17$ & $241 / 46$ \\
\hline 11 & 5 & 27.773 & 1.061 & 1.109 & 1.181 & 0.330 & $240 / 22$ & $087 / 56$ & $328 / 18$ \\
\hline 12 & 6 & 9.757 & 1.132 & 1.207 & 1.369 & 0.209 & $050 / 05$ & $319 / 08$ & $168 / 81$ \\
\hline 13 & 4 & 10.144 & 1.147 & 1.155 & 1.325 & 0.020 & $056 / 20$ & $327 / 01$ & $232 / 70$ \\
\hline 14 & 6 & 34.407 & 1.043 & 1.129 & 1.185 & 0.501 & 059/08 & $161 / 52$ & $323 / 37$ \\
\hline 15 & 5 & 6.553 & 1.040 & 1.216 & 1.288 & 0.718 & $202 / 31$ & $093 / 29$ & $328 / 45$ \\
\hline 16 & 5 & 7.164 & 1.032 & 1.160 & 1.213 & 0.628 & $117 / 56$ & $232 / 12$ & $336 / 21$ \\
\hline 17 & 5 & 4.233 & 1.081 & 1.144 & 1.239 & 0.274 & $213 / 01$ & $118 / 34$ & $311 / 58$ \\
\hline 18 & 6 & 11.339 & 1.180 & 1.148 & 1.355 & -0.095 & $217 / 15$ & $094 / 63$ & $315 / 25$ \\
\hline 19 & 5 & 11.557 & 1.119 & 1.354 & 1.539 & 0.467 & $064 / 11$ & $329 / 03$ & $217 / 72$ \\
\hline 20 & 5 & 5.850 & 1.214 & 1.206 & 1.464 & -0.020 & $056 / 02$ & $146 / 22$ & $321 / 68$ \\
\hline 21 & 8 & 10.144 & 1.039 & 1.124 & 1.176 & 0.497 & $103 / 01$ & $193 / 37$ & $012 / 53$ \\
\hline 22 & 5 & 23.624 & 1.091 & 1.183 & 1.297 & 0.319 & $122 / 07$ & $219 / 52$ & $026 / 37$ \\
\hline 23 & 6 & 12.382 & 1.026 & 1.116 & 1.181 & 0.665 & $160 / 46$ & $64 / 06$ & $329 / 43$ \\
\hline 24 & 5 & 0.487 & 1.031 & 1.035 & 1.068 & 0.055 & $047 / 02$ & $316 / 79$ & $133 / 10$ \\
\hline 25 & 7 & 18.914 & 1.231 & 1.097 & 1.364 & -0.323 & $255 / 11$ & $154 / 04$ & $065 / 73$ \\
\hline 26 & 4 & -0.004 & 1.030 & 1.087 & 1.124 & 0.487 & $285 / 25$ & $077 / 58$ & $187 / 13$ \\
\hline 27 & 7 & 1.834 & 1.236 & 1.160 & 1.439 & -0.177 & $250 / 15$ & $348 / 27$ & $135 / 59$ \\
\hline 28 & 12 & 0.330 & 1.023 & 1.124 & 1.188 & 0.676 & $250 / 09$ & $352 / 19$ & $139 / 61$ \\
\hline 29 & 4 & 1.418 & 1.086 & 1.084 & 1.177 & -0.011 & $300 / 01$ & 069/06 & $031 / 80$ \\
\hline 30 & 4 & 21.356 & 1.033 & 1.102 & 1.144 & 0.502 & $113 / 21$ & $210 / 19$ & $337 / 61$ \\
\hline 31 & 5 & 12.865 & 1.036 & 1.134 & 1.184 & 0.565 & $149 / 50$ & $024 / 27$ & $279 / 27$ \\
\hline 32 & 6 & 6.304 & 1.019 & 1.053 & 1.075 & 0.444 & $235 / 12$ & $053 / 80$ & $145 / 01$ \\
\hline 33 & 4 & 4.306 & 1.068 & 1.016 & 1.090 & -0.547 & - & - & - \\
\hline 34 & 9 & 19.023 & 1.070 & 1.087 & 1.165 & 0.102 & $127 / 23$ & $222 / 03$ & $312 / 07$ \\
\hline 35 & 4 & 13.005 & 1.164 & 1.120 & 1.345 & -0.026 & $222 / 22$ & $100 / 52$ & $327 / 28$ \\
\hline 36 & 4 & 0.112 & 1.002 & 1.007 & 1.010 & 0.572 & $225 / 30$ & $135 / 10$ & $044 / 66$ \\
\hline 37 & 7 & 10.744 & 1.045 & 1.181 & 1.250 & 0.582 & $284 / 11$ & $015 / 05$ & $110 / 77$ \\
\hline 38 & 4 & 34.427 & 1.058 & 1.171 & 1.249 & 0.475 & $302 / 28$ & $045 / 07$ & $150 / 66$ \\
\hline 39 & 7 & 21.681 & 1.080 & 1.095 & 1.183 & 0.092 & $282 / 16$ & $193 / 27$ & $029 / 64$ \\
\hline 40 & 4 & 31.463 & 1.047 & 1.074 & 1.126 & 0.220 & $277 / 03$ & $023 / 38$ & $194 / 47$ \\
\hline
\end{tabular}

\section{MICROTEXTURES}

In most of the of the pluton, where granodiorite and monzonite prevail, the rocks appear macroscopically isotropic. However, it is in these parts that AMS measurements record the NW-SE trending magnetic anisotropy. This direction does not match any tectonic fabric known anywhere in the Rhodope, which constantly presents only NE-SW stretching lineations. For this reason we re- 
examined outcrops of these rocks and studied oriented samples cut parallel and normal to the NW$\mathrm{SE}$ direction. What we found macroscopically is that platy microgranular enclaves $\mathrm{cm}$ to $\mathrm{dm}$ scales, although dipping at various angles, are constantly subparallel to the NW-SE direction. In a few cases a faint NW-SE trending lineation was also visible in the field.

Under the microscope, even the most isotropic looking rocks with typical magmatic textures and no indication of solid state deformational reworking apart from incipient undulose extinction in quartz (Plate | $a, b$ ), reveal a plagioclase orientation anisotropy. Most of the platy plagioclase crystals have their long axes parallel to the NW-SE direction (Plate Ic). In the same rocks a rather well defined NW-SE orientation of "strings" of magnetite crystals, and to some extent of hornblende, can be seen (Plate Id). All the above lead us to suggest that the NW-SE directed fabric is of magmatic origin and has been clearly recorded by AMS. A NW-SE directed "magmatic movement" can be deduced, although this was apparently more complicated than a simple laminar flow.
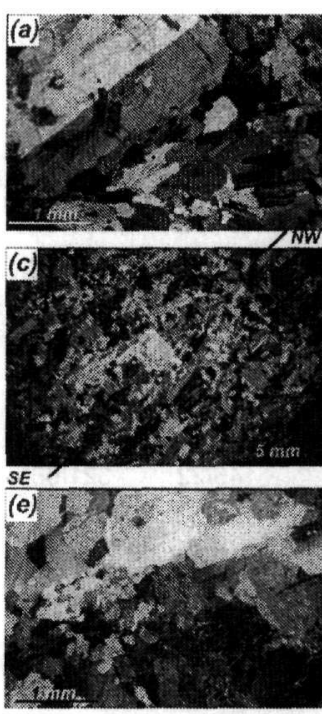
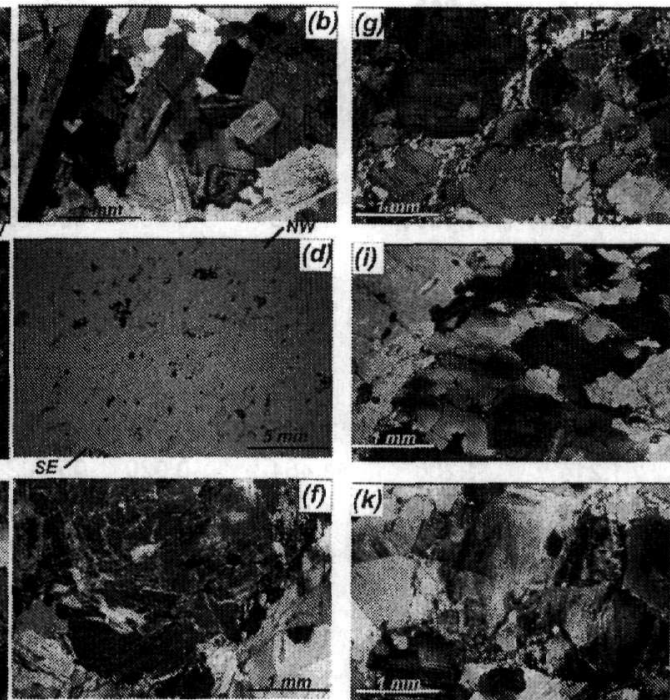
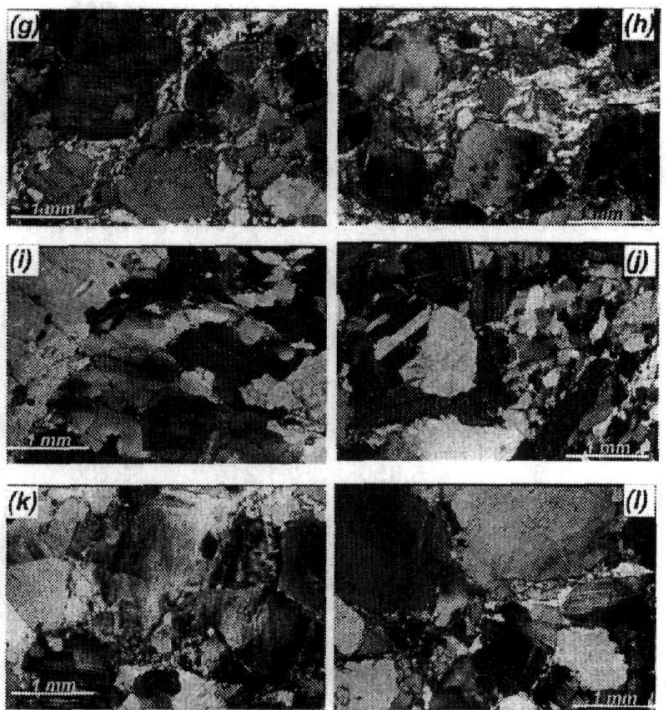

Plate I. Eastern (a-f) and Western ( $g-1)$ Vrondou photomicrographs.

(a)-(b) Magmatic textures in the monzonites, (c)-(d) Subparallel alignment of plagioclase laths, (c) and of femics and opaques, (d) Same thin section and field of view with crossed polars (XPL) (c) and plain polarized light (PPL) (d), (e) Quartz mosaics in a slightly deformed rock, (f) Marginal dislocation and recrystallization of a plagioclase megacryst, (g)-(h) Mylonitic fabric in quartz monzonites, (i)-(j) Dynamic recrystallization of quartz in quartz monzonites, (k)Recrystallized dislocations in feldspars, (l) Streams of microgranular quartz matrix.

In the same eastern part of the pluton there are places where the rocks show indications of plastic deformation, with a NE-SW trending mineral lineation on flat subhorizontal shearing surfaces. Under the microscope the solid state plastic reworking of the rock is testified by the dynamic recrystallization of quartz which turns into mosaic multigrains (Plate le), by broken and annealed feldspar megacrysts (Plate If) and by a new NE-SW alignment of smaller plagioclase crystals, femics and opaques. True mylonitic fabrics however are lacking.

In the western part of the pluton (Early Miocene in age) large tracts of quartz monzonite and granite, the most common types there, have been pervasively deformed by a top to the SW shear, which resulted in NE-SW trending mineral lineations. Original magmatic textures have been generally overprinted by solid-state plastic deformation, which in a few cases continued until reaching semi-brittle conditions. Dynamic recrystallization of quartz, development of deformational twins in plagioclase, "mechanical abrasion" of feldspar crystals and "flow" of a microgranular quartz matrix round them are very common features in these mylonitized rocks (Plate I g,h). The magnetic lineation in these rocks matches perfectly the observed tectonic fabric.

The few sites in the western part of the pluton where magnetic lineations deviate significantly from the regional NE-SW trend, turning towards the NW-SE direction, correspond to rocks that apparently escaped intense sub-solidus reworking by the NE-SW trending shearing. In these rocks, apart from local dynamic recrystallization of quartz, recrystallized dislocations in feldspars and for- 
mation of some streams of microgranular quartz matrix (Plate $\mid \mathrm{i}, \mathrm{j}, \mathrm{k}, \mathrm{l}$ ), the original magmatic texture has not changed much and no new mineral alignments were developed. It is therefore very likely that the magnetic anisotropy in these rocks also records to a large degree the original magmatic flow orientation, which we believe was also NW-SE oriented, as was in eastern Vrondou.

\section{DISCUSSION AND CONCLUSIONS}

In both parts of the Vrondou pluton, but especially in the older (Mid-Oligocene) eastern part, an original magmatic fabric indicates that magmatic flow was NW-SE oriented, though no specific direction of flow can be deduced. Also in both parts of the pluton, but especially in the younger (Early Miocene) western part, a regional NE-SW oriented subhorizontal shear, with top to the SW sense, overprints the original magmatic texture, developing a NE-SW oriented mineral lineation. AMS measurements have detected the original magmatic and the sub-solidus tectonir, fabrics in both parts of the pluton.

Two questions arise from the above: $a$. is it significant that the direction of magmatic flow appears to be nearly normal to the shear direction in both the Mid-Oligocene and the Early Miocene intrusions? b. why has NE-SW shear affected more intensely the western, younger part of the pluton than the eastern, older part of it? Likely answers to the above questions will be given in the discussion that follows on the emplacement mechanism of the Vrondou pluton.

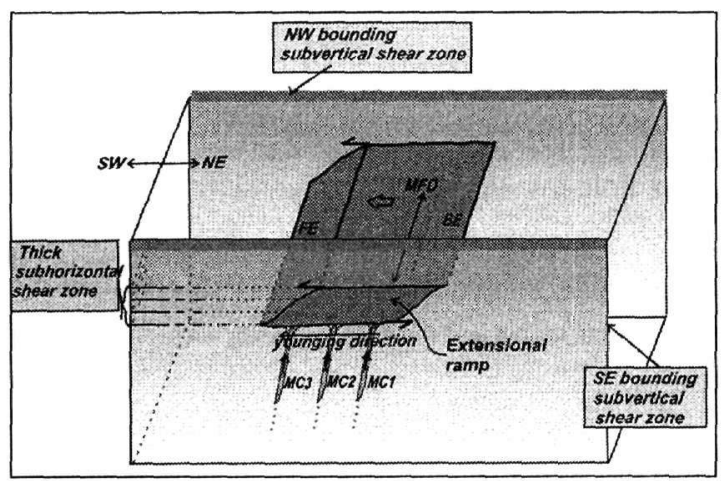

Figure 6. 3D diagram showing the mechanism of emplacement of the Vrondou pluton. FE: Frontal edge of the extensional ramp (younger intrusions), BE: back edge of the extensional ramp (older intrusions), MC: Ascending magma conduits, MFD: Main magmatic flow direction.

The emplacement model we present is inspired from one already proposed by Kolokotroni \& Dixon (1991) and Kolokotroni (1992). Following these authors we envisage a subhorizontal extensional ramp space at mid crustal levels (Fig. 6) formed by the regional top to the SW shear movement in the Rhodope, active during the Mid Oligocene to Early Miocene period. A box-like extensional ramp space was incrementally widening and was simultaneously being filled with batches of magma generated at deeper levels. Free space for the influx of magma within the extensional ramp was provided by the southwestward movement of its frontal edge in relation to its back edge, and this may have been accommodated by strike-slip movements on two subvertical shear zones bounding the ramp space from NW and SE. According to Kolokotroni \& Dixon (1991) and Kolokotroni (1992) a subvertical shear zone at the southwestern border of the pluton was active during the latest stage of extension when conditions changed from ductile to brittle. Such structures may however be the last traces of earlier, longer lasted subvertical ductile shear zones, of which little evidence may have been left, especially after their possible function as bordering walls during the pluton exhumation. If such steep, deep reaching shear zones did actually bound the extensional ramp space, then could have also acted as paths for the ascending magma, which was therefore entering from the NW or SE the gradually developing ramp space and was filling it by steaming along a NW-SE direction. Early magmatic intrusions were attached to the back edge of the ramp space, while new space was developing in its frontal edge. 
The stronger imprint of the NE-SW shearing in the Early Miocene rocks in the west, as compared to the Mid Oligocene ones in the east, may be the result of any, or of a combination of the following three, not mutually exclusive factors. The first is that the rate of regional shear movement may have been higher by Early Miocene in relation to the Mid Oligocene; therefore, the more deformable hotter rock in the west took most of the strain, whereas the colder rock in the east was left with only the feeble deformation imposed on it shortly after its emplacement in the Mid Oligocene. The second is that the younger rocks in the west were more deformable due to their high quartz and biotite content in relation to the less silica saturated, hornblende bearing older rock types in the east. The third is that the initial stages of activation of the Strymon detachment may have especially affected the western parts of the pluton in addition to the deformation imposed by the regional Mid Tertiary shearing. The Strymon detachment, a clearly Neogene brittle structure, bounds the Vrondou pluton from the west and is related (it was actually responsible for) the starting of its exhumation. The direction and sense of movement of this detachment are the same with the mid Tertiary regional shearing. It may be that the initiation of the Strymon detachment was actually the gradual localization of the thick mid Tertiary subhorizontal shear zone into a much thinner zone within it, before ending up at a single brittle detachment surface. This localization probably started before the Middle Miocene, since by that time sediments were deposited in extensional basins already opened by the Strymon detachment (Dinter \& Royden 1993). The restriction of shear movement near the western margin of the Vrondou pluton by the Early to Middle Miocene may have strongly affected its western parts as long as they were still hot.

\section{ACKNOWLEDGEMENTS}

The first author thanks the National Grant Foundation of Greece for financial support. Mary Kovacheva, Roberto Lanza and Antony Morris are gratefully acknowledged for allowing the use of the facilities at their laboratories and providing helpful advice. R. Trindade, Ch. Zananiri and S. Zananiri are warmly thanked for their help in the field. The paper benefited from the reviews of Simo Spassov and an anonymous referee. This is Geophysical Laboratory of the Aristntle University of Thessaloniki contribution number \# 640/2004.

\section{REFERENCES}

Borradaile, G.J. \& Henry, B. 1997. Tectonic applications of magnetic susceptibility and its anisotropy. EarthScience Reviews, 42, 49-93.

Bouchez, J.-L. 1997. Granite is never isotropic: an introduction to AMS studies in granitic rocks. From: Bouchez, J.L., Hutton, D.H.W., Stephens, W.E. (eds.), Granite: From Segregation of Melt to Emplacement Fabrics. Kluwer Academic Publishers, Dortrecht, pp. 95-112.

Bouchez, J.-L., Gleizes, G., Djouadi, T. \& Rochette, P. 1990. Microstructure and magnetic susceptibility applied to emplacement kinematics of granites : the example of the Foix pluton (French Pyrenees). Tectonophysics, 184 157-171.

Burg, J. P., Ivanov, Z., Ricou, L. E., Dimor, D. \& Klain, L. 1990. Implications of shear-sense criteria for the tectonic evolution of the central Rhodope massif, southern Bulgaria. Geology, 18, 451-454.

Burg, J. P., Godfriaux, I. \& Ricou, L. E. 1995. Extension of the Mesozoic Rhodope thrust units in the VertiskosKerdilion Massifs (Northern Greece). C. R. Acad. Sci. Paris, 320 lia, 889-896.

Christofides, G. 1977. A contribution to the study of the plutonic rocks of Xanthi area. PhD thesis, Aristotle University of Thessaloniki.

Christofides, G., Koroneos, A., Soldatos, T., Eleftheriadis, G. \& Kilias, A. 2001. Eocene magmatism (Sithonia and Elatia plutons) in the Internal Hellenides and implications for Eocene-Miocene geological evolution of the Rhodope Massif (Northern Greece). Acta Vulcanologica, 13 (1-2), 73-89.

Cisowski, S. 1981. Interacting vs. non-interacting single domain behavior in natural and synthetic samples. Physics of the Earth and Planetary Interiors, 26, 56-62.

Dimitriadis, S. 1995. A likely petrological evidence for large scale southwestward displacement of the Serbomacedonian over the Pangaion Unit in Late Tertiary. Geological Society of Greece, Special Publications, No 4, 21-23.

Dimitriadis, S., Kondopoulou, D. \& Atzemoglou, A. 1998. Dextral rotations and tectonomagmatic evolution of the southern Rhodope and adjacent regions (Greece). Tectonophysics, 299, 159-173. 
Dinter, D. 1991. Neogene detachment faulting and the Rhodope metamorphic core complexes, northern Greece. EOS Trans. AGU, 72(44), Fall Meet. Suppl., 460.

Dinter, D. A. 1994. Tectonic evolution of the Rhodope metamorphic core complex, northeastern Greece. PhD thesis, 320 pp., Mass. Inst. of Technol., Cambridge.

Dinter, D. A. \& Royden, L. H. 1993. Late Cenozoic extension in northeastern Greece: Strymon Valley detachment and Rhodope metamorphic core complex. Geology, 21, 45-48.

Dinter, D., Macfarlane, A., Hames, W., Isachnsen, C., Bowring, S. \& Royden, L. 1995. U-Pb and ${ }_{40} A r /{ }_{39} A r$ geochronology of the Symvolon granodiorite: Implications for the thermal and structural evolution of the Rhodope metamorphic core complex, northeastern Greece. Tectonics, 14, 4, 886-908.

Jelinek, V. 1981. Characterization of the magnetic fabric of rocks. Tectonophysics, 79, T63-T67.

Jones, E. C., Tarney, J., Baker, J. \& Gerouki, F. 1992. Tertiary granitoids of the Rhodope, northern Greece: magmatism related to extensional collapse of the Hellenic Orogen? Tectonophysics, 210, 295-314.

Kaufman, P. S. 1995. Extensional tectonic history of the Rhodope metamorphic core complex, Greece, and geophysical modeling of the Halloran Hills, California. PhD thesis, Mass. Inst. of Technol., Cambridge, 295 pp.

Kilias, A. A. \& Mountrakis, D. M. 1998. Tertiary extension of the Rhodope massif associated with granite emplacement (Northern Greece). Acta Vulcanologica, 10 (2), 331-337.

Kilias, A., Tranos, M., Orozco, M., Alonso-Chaves, F. \& Soto, J. 2002. Extensional collapse of the Hellenides: a review. Rev. Soc. Geol. Espana, 15 (3-4), 129-139.

Kolokotroni, C. 1992. The emplacement and petrogenesis of the Vrodou granitoid pluton, Rhodope massif, NE Greece. PhD thesis, University of Edinburgh, 425pp.

Kolokotroni, C. N. and Dixon, J. E. 1991. The origin and emplacement of the Vrondou granite, Serres, NE Greece. Bulletin of the Geological Society of Greece, 25, 469-483.

Koukouvelas, J. \& Doutsos, T. 1990. Tectonic stages along a traverse cross cutting the Rhodope zone (Greece). Geol. Rundsch. 79, 3, 753-776.

Kronberg, P. 1969. Petrografie und Tectonik im Rhodopen-Kristallin des Tsal-Dag, Simvolon und Ost-Pangaon (Griechisch-Makedonien). N. J. Geol. Pal. Abh., 7, 140-156.

Kronberg, P., Meyer, W. \& Pilger, A. 1970. Geologie der Rila-Rhodope-Masse zwischen Strimon und Nestos (Nordgriechenland). Beih. geol. Jb. 88, 133-180.

Kyriakopoulos, K.G. 1987. A geochronological, geochemical and mineralogical study of some Tertiary plutonic rocks of the Rhodope Massif and their isotopic characteristics. PhD thesis, University of Athens, 343pp.

Lowrie, W. \& Fuller, M. 1971. On the alternating field demagnetization characteristics of multidomain thermoremenent magnetization in magnetite. Journal of Geophysical Research, 76, 6339-6349.

Mposkos, E. 1998. Cretaceous and Tertiary tectonometamorphic events in Rhodope zone (Greece). Petrological and geochronological evidences. Bulletin of the Geological Society of Greece, vol. XXXII/3, 59-67.

Papadakis, A.N. 1965. The Serres-Drama pluton. PhD thesis, Aristotle University of Thessaloniki, 130pp.

Sklavounos, S. 1981. The Paranestion granite. Mineralogy-Petrography. PhD thesis, University of Thessaloniki, Greece, 175pp.

Soldatos, T. 1985. Petrology and geochemistry of the Elatia pluton. PhD thesis, and Scientific Annales of the Faculty of Sciences, University of Thessaloniki, Greece, 23 (37), 303pp.

Soldatos, T., Poli, G., Christofides, G., Eleftheriadis, G., Koroneos, A. \& Tommasini, S. 1998. Petrology and evolution of transitional alkaline-subalkaline granitoids from Vrondou (NE Greece): evidence for fractional crystallization and magma mixing. Acta Vulcanologica, 10 (2), 319-330.

Theodorikas, S. 1982. The mineralogy, petrology and geochemistry of the Serres-Drama granitic complex, northern Greece. PhD Thesis, University of Keele, and Scientific Annales of the Faculty of PhysicsMathematics, University of Thessaloniki, 22, no.28, Thessaloniki. 1983, 415 pp.

Trindade, R., Raposo, I., Ernesto, M. \& Siqueira, R. 1999. Magnetic susceptibility and partial anhysteretic remanence anisotropies in the magnetite-bearing granite pluton of Tourao, NE Brazil. Tectonophysics, 314, 443-468.

Zananiri, I., Dimitriadis, S., Kondopoulou, D. \& Atzemoglou, A. 2002. A preliminary AMS study in some Tertiary granitoids from Northern Greece: integration of tectonic and paleomagnetic data. Physics and Chemistry of the Earth, 27, 25-31, 1289-1297. 